\title{
Not Just in English Anymore: Government Documents in Other Languages
}

\section{A Disaster y un Desastre are the Same}

\section{Jane Canfield}

T hink about a disaster that you have never experienced personally or that occurs in other areas but not where you live. For me, that is a wildfire. Now, imagine that the only available information is in a language you cannot read or understand. For my first few years living in Puerto Rico that was me.

Now, you have an idea of why it's important to provide reliable government information in other languages to our users. My users all speak Spanish and when a disaster looms, like Hurricane Maria two years ago, they are anxious and scared and really need information on what to do and how to prepare in their native Spanish. Maybe some of your users are Spanish speakers and maybe some of them speak Chinese or any other of the many languages spoken in the US.

When a disaster is ongoing, the principal agencies of the US government involved are the National Weather Service (NWS), the United States Geological Survey (USGS), and the Federal Emergency Management Agency (FEMA). Each of these agencies also provides extensive information in Spanish about disasters.

For general information in Spanish, this website offers help: https://www.usa.gov/espanol/desastres-y-emergencias.

This is a general entry site for usa.gov/español and provides links to a variety of information including preparation for a disaster, recuperation after a disaster and financial aid after a disaster.

For general information in a number of other languages the internet site of ready.gov offers help in 21 languages other than English: https://www.ready.gov/. This is a general site for disaster preparation which includes information in Spanish, French, Portuguese, Tagalog, German, Italian, Yiddish and a number of Asian languages. The site provides information on preparation for a disaster and includes information on a variety of different types of disasters. The extensive list includes active shooter incidents, avalanches, cybersecurity, droughts, earthquakes, extreme heat, explosions, floods, hurricanes, landslides, pandemics, tornadoes, tsunamis, volcanoes and wildfires.

This site also includes specific information for children on disasters. There are multiple lists for preparing family plans for disasters which include pets, persons with disabilities, children and senior citizens. In addition, the site explains how to sign up for emergency alerts on your phone.

Probably the best known US government agency for disaster information and help is FEMA, the Federal Emergency Management Agency: https://www.fema.gov/: FEMA provides assistance after disasters of all types. The site includes information on how FEMA functions, the laws which regulate FEMA, forms to solicit aid, and preparation for disaster information. FEMA provides information in a variety of languages including Spanish, Haitian Creole, German, Vietnamese, and Portuguese.

A number of US government agencies provide information on specific types of disasters. These agencies include The National Weather Service, The United States Geological Survey, the US Forest Service and the Centers for Disease Control.

Table 1 provides information on these agencies and the type of disasters for which information is provided.

Un desastre es un desastre, but a disaster is easier if you have information in your own native language.

Jane Canfield (jcanfield@pucpr.edu), Depository Coordinator, Pontifical Catholic University of Puerto Rico. 
Table 1. Specific Disaster Information Provided by U.S. Government Agencies

\begin{tabular}{|c|c|c|c|c|c|c|c|c|}
\hline Agency & Other Languages & Tornadoes & Hurricanes & $\begin{array}{l}\text { Earth- } \\
\text { quakes }\end{array}$ & Floods & Wildfires & $\begin{array}{l}\text { Winter } \\
\text { Weather }\end{array}$ & Other \\
\hline $\begin{array}{l}\text { https://www.weather.gov/ } \\
\text { National Weather Service }\end{array}$ & $\begin{array}{l}\text { For selected areas } \\
\text { in certain types } \\
\text { of disasters }\end{array}$ & $x$ & $x$ & & $x$ & $x$ & $x$ & \\
\hline $\begin{array}{l}\text { https://www.usgs.gov/ } \\
\text { United States Geological } \\
\text { Survey }\end{array}$ & $\begin{array}{l}\text { Some publications } \\
\text { in Spanish }\end{array}$ & & & $\begin{array}{l}x \\
\text { Information } \\
\text { in real-time }\end{array}$ & $x$ & & & $\begin{array}{l}\text { Volcanoes } \\
\text { Landslides }\end{array}$ \\
\hline $\begin{array}{l}\text { https://www.fs.fed.us } \\
\text { /science-technology } \\
\text { /fire/information } \\
\text { US Forest Service Internet } \\
\text { page which provides } \\
\text { fire information }\end{array}$ & $\begin{array}{l}\text { Some information } \\
\text { and publications } \\
\text { in Spanish }\end{array}$ & & & & & $\begin{array}{l}x \\
\text { An } \\
\text { interactive } \\
\text { Wildfire } \\
\text { map }\end{array}$ & & \\
\hline $\begin{array}{l}\text { https://www.cdc.gov } \\
\text { /disasters/disaster_ } \\
\text { resources.html } \\
\text { Internet page of the } \\
\text { CDC which offers } \\
\text { information on disasters }\end{array}$ & $\begin{array}{l}\text { Entire site can be } \\
\text { changed to Spanish } \\
\text { Materials offered in } \\
23 \text { other languages. }\end{array}$ & $x$ & $x$ & $x$ & $x$ & $x$ & $x$ & $\begin{array}{l}\text { Volcanoes } \\
\text { Tsunamis } \\
\text { Chemical } \\
\text { and } \\
\text { biological } \\
\text { disasters }\end{array}$ \\
\hline $\begin{array}{l}\text { https://www.disaster } \\
\text { assistance.gov/ } \\
\text { Internet page with an } \\
\text { application to apply for } \\
\text { financial aid after a disaster }\end{array}$ & $\begin{array}{l}\text { Entire site can be } \\
\text { changed to Spanish }\end{array}$ & $x$ & $x$ & $x$ & $x$ & $x$ & $x$ & $\begin{array}{l}\text { Volcanoes } \\
\text { Tsunamis } \\
\text { Chemical } \\
\text { and } \\
\text { biological } \\
\text { disasters }\end{array}$ \\
\hline
\end{tabular}

